IRSH 50 (2005), Supplement, pp. I-23 DOI: I0.10I7/S002085900500204x

(C) 2005 Internationaal Instituut voor Sociale Geschiedenis

\title{
Endogamy and Social Class in History: An Overview*
}

\author{
Marco H.D. VAN LEEUWEN AND InEKe MaAs
}

\section{INTRODUCTION}

The social identities of marriage partners [...] are among the most sensitive and acute indicators of community or class feelings. Who marries whom, without courting alienation or rejection from a social set, is an acid test of the horizons and boundaries of what each particular social set regards as tolerable and acceptable, and a sure indication of where that set draws the line of membership. ${ }^{\mathrm{I}}$

It took a marriage to reproduce a class structure, or to alter it, as Thompson claimed for England in the nineteenth century. Kocka too, in his study of class formation in Germany, noted that the essence of class formation is the process of simultaneous closure of marital barriers between certain social groups and the blurring of barriers between others. ${ }^{2}$

Given the importance for social history of marriage patterns by social class, it is remarkable that historians have studied endogamy by region and age much more than endogamy by social class. ${ }^{3}$ Endogamy by social class is also known as social endogamy or social homogamy (we use the terms interchangeably here, although, strictly speaking, social endogamy refers to marrying within the same class - and thus assumes the existence of a limited number of discrete classes - while social homogamy refers to marrying someone of approximately the same status - and thus assumes the existence of a continuous status scale). Scholars from other disciplines, notably sociology, have written more on social endogamy. Sociologists

\footnotetext{
* We are grateful to Jos Dessens, Chris Gordon, Wim Jansen, Jan Kok, Frank van Tubergen, Lex Heerma van Voss, Richard Zijdeman, and members of the editorial committee of this journal for their comments.

I. F.M.L. Thompson, The Rise of Respectable Society: A Social History of Victorian Britain, I830-I900 (London I988), p. 93.

2. J. Kocka, "Family and Class Formation: Intergenerational Mobility and Marriage Patterns in Nineteenth-Century Westphalian Towns", Journal of Social History, I7 (1984), pp. 4I I-433; idem, "Problems of Working-Class Formation in Germany: The Early Years I 800-1875", in I. Katznelson and A.R. Zolberg (eds), Working-Class Formation: Nineteenth-Century Patterns in Western Europe and the United States (Princeton, NJ, I986), pp. 279-35 I.

3. See for example Guy Brunet, Antoinette Fauve-Chamoux, and Michel Oris (eds), Le choix du conjoint (Paris, 1996); Christophe Duhamelle and Jürgen Schlumbohm (eds), Eheschließungen im Europa des I8. und 19. Jabrbunderts. Muster und Strategien (Göttingen, 2003); R. Gehrmann (ed.), Determinanten und Muster des Heiratsverhaltens in Europa in der Neuzeit: Ausgewäbtle Fallstudien, special issue, Historische Sozialforschung, 28 (2003).
} 
have dealt with contemporary patterns and their determinants to a greater degree than with the long-term historical trends that escape survey data. Nonetheless, their valuable work - notably on the determinants of social endogamy - can be usefully consulted, since it yields insights that can be tested against the historical record, thus furthering our understanding of processes of class formation in the past and also establishing, or questioning, the validity of theoretical notions.

By and large, a few groups of key questions recur in the literature on marriage and social class, and, for that matter, in much of the literature dealing with social inequality. One set of questions in the literature on endogamy by social class focuses on geographical and temporal variations in patterns of endogamy. Were there regional differences in who married whom, and did these change over time? If so, did these regional patterns converge or diverge? A second set of questions focuses on determinants of endogamy. What factors determine who marries whom? And has the relative importance of these factors changed over time? A third set of questions relates to the durability of social inequality, as measured by the mobility a society allows it members.

Stratification sociologists often look at the degree of intergenerational class mobility, or indeed of marital mobility, to judge the "social fluidity" or "openness" of a society. ${ }^{4}$ Equipped with such information, it is possible to look at a fourth and final set of questions on the consequences of differences in processes of class formation for social and political relationships. One can speculate, for example, to what extent major differences between countries in patterns of inequality, labour relations,

4. P. Sorokin, Social and Cultural Mobility (New York, I959), pp. I $38-14 \mathrm{I}$; D.V. Glass, Social Mobility in Britain (London, 1954); S.M. Lipset and R. Bendix (eds), Social Mobility in Industrial Society (Berkeley, CA, I959); C. Tilly, The Vendéé (Cambridge, MA, 1964), pp. 93-99; P.M. Blau and O.D. Duncan, The American Occupational Structure (New York, 1967); A. Sharlin, "From the Study of Social Mobility to the Study of Society", American Journal of Sociology, 85 (1979), pp. 338-360; M. Hout, "The Association Between Husbands' and Wives' Occupations in Two-Earner Families", American Journal of Sociology, 88 (1982), pp. 397-409; H. Sixma and W. Ultee, "Marriage Patterns and the Openness of Society: Educational Heterogamy in the Netherlands in 1959, 1971 and 1977", in B.F.M. Bakker, J. Dronkers, and H.B.G. Ganzeboom (eds), Social Stratification and Mobility in the Netherlands (Amsterdam, 1984), pp. 91-108; P.M. Horan, "Occupational Mobility and Historical Social Structure", Social Science History, 9 (1985), pp. 25-47; F.L. Jones, "Marriage Patterns and the Stratification System: Trends in Educational Homogamy since the I930s", Australian and New Zealand Journal of Sociology, 23 (1987), pp. 185-193; Robert D. Mare, "Five Decades of Educational Assortative Mating", American Sociological Review, 56 (1991), pp. I 5-32; I.K. Fukumoto and D.B. Grusky, "Social Mobility and Class Structure in Early Industrial France", in A. Miles and D. Vincent (eds), Building European Society: Occupational Change and Social Mobility in Europe 1840-1940 (Manchester, 1993); A. Miles, “How 'Open' Was Nineteenth Century British Society? Social Mobility and Equality of Opportunity", in ibid.; W. Uunk, Who Marries Whom? The Role of Social Origin, Education and High Culture in Mate Selection of Industrial Societies during the Twentieth Century (Nijmegen, 1996). 
and social unrest can be explained by differences in social stratification and class mobility. This type of question has been posed notably with regard to intergenerational mobility, but it can also be asked with regard to marriage patterns according to social class. For example, from Karl Marx and Werner Sombart onward, scholars have attributed the absence of a large socialist party in the United States - in contrast to many European countries - to the greater permeability of social class boundaries there. 5

Given the importance of social endogamy for social and labour history, it is fortunate that so many scholars have contributed to the present volume. Each contribution is a case study that sheds light on a number of key questions. The findings are much more comparable than was previously the case in this type of research, since all the contributors have used the same social-class scheme. This also makes it possible to undertake a comparative analysis of the data underlying these case studies (see the conclusion to this volume). Is it a permissible exaggeration to claim that these studies mark the commencement in earnest of the global comparative study of partner choice according to social class in the past? ${ }^{6}$

A prime reason why no comparative study on this central theme in social history has hitherto appeared is the fact that until recently it was impossible to allocate the same occupations in different regions and

5. Karl Marx, The Eighteenth Brumaire of Louis Napoleon (New York, I 8 52); W. Sombart, Why Is There No Socialism in America? (New York, 1976), first published in German in 1906, esp. p. I I5; S. Thernstrom, The Other Bostonians: Poverty and Progress in the American Metropolis I880-1970 (Cambridge, MA, I973), esp. pp. 258-259. The question of how to explain American exceptionalism has continued to arouse interest. See for example K. Voss, The Making of American Exceptionalism: The Knights of Labor and Class Formation in the Nineteenth Century (Ithaca, NY [etc.], I993), and the special supplement to Historical Materialism, I I (2003). It remains to be seen, of course, whether the social fluidity in the USA during the nineteenth and early twentieth centuries was indeed greater than that in Europe. See J. Long and J. Ferrie, "A Tale of Two Labor Markets: Intergenerational Occupational Mobility in Britain and the US since I 850 ", NBER Working Paper No. I 253 (April 2005).

6. Of course, valuable historical single case studies of marriage patterns according to social class do exist. See for example A. Daumard, "Les relations sociales l'époque de la Monarchie Constitutionelle d'après les registres paroissaux des mariages”, Population, I 2 (I957), pp. 445466; A. Daumard, "Structures et relations sociales: Paris au milieu de XVIIIe siècle", Cabier des Annales, I8 (1961); R.D. Penn, Skilled Workers in the Class Structure (Cambridge, 1985), pp. I 58-i 82; P. Borscheid, "Romantic Love or Material Interest: Choosing Partners in NineteenthCentury Germany”, Journal of Family History, i I (1986), pp. I 57-I68; D. Mitch, “'Inequalities Which Everyone May Remove': Occupational Recruitment, Endogamy, and the Homogeneity of Social Origins in Victorian England", in Miles and Vincent, Building European Society, pp. I40-164; A. Miles, Social Mobility in Nineteenth- and Early Twentieth-Century England (Basingstoke, 1999). For a study comparing mobility patterns in several German regions using the same social-class scheme see R. Schüren, Soziale Mobilität: Muster, Veränderungen und Bedingungen im 19. und 20. Jabrhundert (St Katharinen, 1989). As far as we are aware, no studies comparing patterns of homogamy among historical populations in different countries have ever appeared before. 
languages to the same classes. ${ }^{7}$ This problem has recently been tackled by developing two comparative tools: HISCO and HISCLASS. Both HISCO, the standard occupational coding scheme, and HISCLASS, the social-class scheme based upon HISCO, were conceived to meet the need to find a way to undertake international social mobility analysis. ${ }^{8}$ Both the coding and the social-class scheme can, however, be used for many other purposes. Occupations form the heart of the world of work, and the world of work is central to social and labour history.

All the contributions to this volume have used the same social-class scheme - more information on HISCLASS is presented in the various contributions as well as in the conclusion to this volume - and as a result their findings can be compared. These contributions cover the past three centuries, with a focus on the nineteenth century, and they take in large or small parts of Austria, Belgium, Brazil, France, the Netherlands, Norway, Sweden, and Switzerland. While this coverage is heavily biased towards Europe, one of the essays in this volume thus deals with a Latin American society.

Social homogamy in the past can be studied using historical sources, notably censuses and vital registration data, including marriage certificates, which are available not just in Europe but also in other parts of the world. Both HISCO and HISCLASS can be used as instruments of global history and have already been tested and applied in different parts of the globe. 9 We hope, therefore, that this volume will be seen as an invitation to historians and other scholars around the world. Even as it is, these essays cover a wide range in terms of chronology and subject: Belgium, the

7. The issue of the non-comparability of the various historical studies on social mobility has been raised, for example, in H. Kaelble, Historical Research on Social Mobility: Western Europe and the USA in the Nineteenth and Twentieth Centuries (London, 1981), and idem, Social Mobility in the 19th and 20th Centuries: Europe and America in Comparative Perspective (Leamington Spa, 1985).

8. Marco H.D. van Leeuwen, Ineke Maas, and Andrew Miles, HISCO: Historical International Standard Classification of Occupations (Leuven, 2002); idem, "Creating an Historical International Standard Classification of Occupations (HISCO): An Exercise in Multi-National, Interdisciplinary Co-Operation", Historical Methods, 37 (2004), pp. I86-197; M.H.D. van Leeuwen and I. Maas, "HISCLASS", paper presented at the sth European Social Science History Conference (Berlin, 24-27 March 2004). See too the individual contributions and the conclusion to this volume for more information on HISCO and HISCLASS, as well as the History of Work Website mentioned below. These three projects originate with the long-established research project HISMA (Historical International Social Mobility Analysis).

9. The History of Work website of the International Institute of Social History (see http:// historyofwork.iisg.nl) contains occupational titles coded into HISCO from the following countries: Belgium, Brazil, Canada (Quebec), Finland, France, Germany, Greece, The Netherlands, Norway, Portugal, Spain, Sweden, UK, and Switzerland. Work on coding occupations in other countries, such as India, Italy, Russia, and the Philippines is currently underway. See, for example, V. Vladimirov (ed.), Istoricheskor professiovedenie. Sbornik nauchnikh statie (Barnaul, 2004). 
leading industrial nation outside Britain; France, which has experienced many major social and economic transformations over the past two centuries; traditional Nordic farming communities; a mountain community (in Austria); and a slave-owning society (Brazil). This wide variety may provide a window on regional and temporal variations in social endogamy and a testing ground for theories on its determinants.

\section{DETERMINANTS OF SOCIAL ENDOGAMY}

Determinants of social-class endogamy can be clustered in various ways. A threefold division between individual preferences, third party influences, and the structural constraints imposed by the marriage market is often used. ${ }^{10}$ We will use the same framework, although we distinguish a total of five clusters. The first and second group of determinants deals with the marriage market. A distinction is made between factors influencing the likelihood of encountering marriage candidates in a given locality, at least long enough to have some sense of whether they would be suitable spouses, and factors dealing with the degree to which geographical marriage horizons shrank or expanded. A third cluster relates to the social pressure from parents, peers, and the community favouring partners from some social classes and rejecting others. The fourth group concerns personal autonomy - the degree to which one can resist such pressure. And, finally, there is a fifth group, that of personal preferences.

\section{Likelibood of meeting on the marriage market}

The opportunity to meet a potential spouse is often seen as an important factor explaining why people marry individuals similar to themselves. ${ }^{\text {II }}$ The marriage market is limited to certain contexts, for example to the neighbourhood where one lives, and these contexts are to some extent already socially homogenous. Thus people end up marrying people similar to themselves even if they have no special desire to do so. The likelihood of meeting may be dissociated into two components: the likelihood of meeting within a certain geographical region, and the likelihood as a function of the size of that region - in other words the "marriage horizon". We begin with a discussion of the first component.

Iо. M. Kalmijn, "Status Endogamy in the United States", American Journal of Sociology, 97 (I991), pp. 496-523, and M. Kalmijn, "Intermarriage and Endogamy: Causes, Patterns, Trends", Annual Review of Sociology, 24 (1998), pp. 395-42 I.

I I. See, for example, P.M. Blau, T.C. Blum, and J.E. Schwartz, "Heterogeneity and Intermarriage”, American Sociological Review, 47 (1982), pp. 45-62; M. Kalmijn and H. Flap, "Assortative Meeting and Mating: Unintended Consequences of Organized Settings for Partner Choices", Social Forces, 79 (200I), pp. I289-I3 I2; Kalmijn, "Intermarriage and Endogamy". 
Mating requires meeting. In the contemporary world, young people might meet at kindergarten, at family gatherings, at school, in the neighbourhood, at church, through sports clubs and other associations, during public celebrations, leisure activities, work, and on the Internet - to list but a few of the more important meeting places that exist. It has been said that, today, school and work are more important in producing socially homogamous marriages than family networks are, and that neighbourhoods do not seem to have this effect. ${ }^{12}$

Young people spend a large part of their youth at school, and thus the people they meet at school form an important pool of those they get to know well enough to consider forming a relationship. ${ }^{13}$ Schooling has of course increased dramatically in virtually all countries in the world over the past two centuries. Primary education has become compulsory in many countries, raising participation rates to extremely high levels. More importantly for endogamy, access to secondary and tertiary education where participants might begin to look for a partner - has generally increased and in many countries become more universal, covering the whole spectrum of society to a larger degree than was formerly the case. One would expect this to lead to higher rates of exogamous marriage, the more so the older the age at which children are stratified into different school levels. ${ }^{14}$ Furthermore, many leisure activities are in some way connected with school, ${ }^{\text {Is }}$ either because schools organize them compulsory swimming classes for example - or, for example, because children from the same school support the same football team (perhaps more so today than in the past). Even if they are not organized by schools, leisure activities are important meeting places for adolescents - all the more so if both boys and girls are actively involved.

The effect of educational expansion has actually been even greater than one might suppose. Whereas schools in Europe in the eighteenth and nineteenth centuries instructed children in the virtues of class immobility ${ }^{16}$ they did so to a lesser extent in the twentieth century. It has been argued that pupils who were taught non-conservative values were

\footnotetext{
I2. Kalmijn and Flap, "Assortative Meeting and Mating”.

I3. At least in the case of co-educational schools.

I4. See Jutta Allmendinger, Career Mobility Dynamics: A Comparative Analysis of the United States, Norway, and West Germany (Berlin, I989).

I 5. See, for instance, M.P. Atkinson and B.L. Glass, "Marital Age Heterogamy and Homogamy, I 900 to I980", Journal of Marriage and the Family, 49 (1985), pp. 685-69I; F. van Poppel and A.C. Liefbroer, "Leeftijdsverschillen tussen huwelijkspartners. Een interpretatie van veranderingen en verschillen in de negentiende en twintigste eeuw", Tijdschrift voor Sociale Geschiedenis, 2 (200I), Pp. I29-I 2.

I6. H. Chisick, The Limits of Reform in the Enlightenment: Attitudes Towards the Education of the Lower Classes in the Eighteenth Century (London, I99I); M.H.D. van Leeuwen, Logic of Charity: A Simple Model Applied to Amsterdam I800-I850 (London, 2000).
} 
more likely to develop an appetite for non-traditional marriages. ${ }^{17}$ However, important differences might have existed between countries such as Britain - with a higher degree of class-specific education, due to the existence of expensive "public" schools - and the Netherlands - where education was less influenced by class and more influenced by religiousbased divisions.

Many people find their spouse at work, and in this respect the varying and historically changing forms of the labour market will have had an impact on endogamy patterns, although as yet we know very little about how this worked. A young man employed at a small workplace will meet fewer women than one working in a large factory or a modern institution such as a post office or a bank, where not only are the "birds" more numerous, they are also of a different feather. The rise of industry and of other large, meritocratic internal labour markets from the mid-nineteenth century onwards led thus, ceteris paribus, to a higher likelihood of marrying outside one's social class. ${ }^{18}$ Other developments in the labour market, such as changes in labour-related migration patterns, might also have influenced social homogamy. ${ }^{19}$

In cities, the social composition of neighbourhoods is another factor influencing marriage patterns by social class, because many people marry someone living close by. So even if they have no intention of marrying within their own class, many will nonetheless do so if their neighbourhood consists of people working in the same trade or type of factory, for

I7. D.J. Treiman, "Industrialization and Social Stratification", in E.O. Laumann (ed.), Social Stratification: Research and Theory for the I970s (Indianapolis, IN, 1970), pp. 207-234; E. Shorter, "Illegitimacy, Sexual Revolution, and Social Change in Modern Europe", Journal of Interdisciplinary History, 6 (1971), pp. 237-272; idem, "Female Emancipation, Birth Control, and Fertility in European History", American Historical Review, 78 (1973), pp. 605-640.

18. Treiman, "Industrialization and Social Stratification"; C. Kerr, J.T. Dunlop, F.H. Harbison, and C.A. Myers, Industrialism and Industrial Man (Cambridge, MA, 1960); Miles and Vincent, Building European Society. The studies by Shorter cited in the previous footnote offer a similar argument: increasing market contacts. A recent survey is offered by John C. Brown, Marco H.D. van Leeuwen, and David Mitch, "The History of the Modern Career: An Introduction", in David Mitch, John C. Brown, and Marco H.D. van Leeuwen (eds), Origins of the Modern Career (Ashgate, 2004), pp. 3-4 I.

I9. In the case of an increase in seasonal migration, for example, one would expect a decrease in homogamy according to social class. For a survey of migration in Europe, see Leslie Page Moch, Moving Europeans: Migration in Western Europe since 1650 (Bloomington, IN, 1992). In societies where it was common for girls to seek employment elsewhere as a servant before marriage, such service could broaden the marriage horizon, not just geographically but also socially, as the girls acquired the social and other skills valued in the social circles of their employers; perhaps the girls also developed a taste for another way of life. See L. Broom and J.H. Smith, "Bridging Occupations", British Journal of Sociology, I 4 (1963), pp. 32 I-334; T. McBride, "Social Mobility for the Lower Classes: Domestic Servants in France", Journal of Social History (1974), pp. 63-78; H. Bras, Zeeuwse meiden. Dienen in de levensloop van vrouwen, ca. 18501950 (Amsterdam 2002). A decrease in service over time would, in that case, mean an increase in social homogamy, while an increase in service would mean the opposite. 
example. ${ }^{20}$ Over the past two centuries, a growing share of the world's population has lived in cities; currently, for the first time in history, more people now live in urban areas than rural areas. The social composition of urban districts might thus have had a considerable impact on social endogamy worldwide.

We know very little about long-term changes in spatial social segregation in cities, however. It is thus possible, for example, that in some cities neighbourhoods were more alike two centuries ago (with spatial segregation within wards being more prevalent than between wards, with, for instance, the upper classes living on the main streets, the middle classes on side streets, and the poor on side streets of side streets) than today (with a few rich neighbourhoods, a large number of mixed neighbourhoods, and mostly poor neighbourhoods). If so, then for those cities the changes in spatial social segregation will have increasingly favoured social endogamy, all other things being equal. We cannot tell, however, in which cities such a process has occurred.

The likelihood of meeting a partner from a particular social group also depends on the size of the various social groups and on their degree of geographical isolation. ${ }^{21}$ If meeting is a random phenomenon, the chances of meeting someone from a particular social class are the product of the relative size of one's own group and the relative size of the other social class. The more heterogeneous a population, the lower the chances of meeting someone from the same social class. If meeting implies mating which of course it does not invariably - a higher degree of social heterogeneity would imply more exogamy. It is not just the sizes of the various social groups that matter; so too does the degree to which they live in geographical isolation. The chances of marrying a coastal fisherman are obviously less for a woman living inland than for one living on the coast, and the likelihood of marrying a farmer is greater for farmers' daughters (since they too live in the countryside) than it is for either coastal inhabitants or urban dwellers.

Further, a population that is religiously (or ethnically) heterogeneous is more likely to be socially exogamous because prospective marriage candidates are selected first on the basis of religion (or ethnicity), thus leaving fewer, if any, marriage partners in the same social group. This

20. P.M. Blau and J.E. Schwartz, Crosscutting Social Circles (New York, I984); William R. Catton, Jr and R.J. Smircich, "A Comparison of Mathematical Models for the Effect of Residential Propinquity on Mate Selection", American Sociological Review, 29 (1964), pp. 522529; Gillian Stevens, "Propinquity and Educational Homogamy", Sociological Forum, 6 (1991), pp. $715-726$.

2 I. Blau and Schwartz, Crosscutting Social Circles; Peter M. Blau, Terry C. Blum, and Joseph E. Schwartz, "Heterogeneity and Intermarriage", American Sociological Review, 47 (1982), pp. 4562; T.C. Blum, "Structural Constraints on Interpersonal Relations: A Test of Blau's Macrosociological Theory", American Journal of Sociology, 9I (1985), pp. 607-6I7. 
would lead one to expect that a country that is more religiously (or ethnically) diverse would have higher exogamy than a country that is less diverse, and that a country that becomes more diverse in the course of time will witness an increase in the proportion of exogamous marriages.

\section{Geographical marriage horizons}

The likelihood of finding a suitable marriage partner depends not only on the degree to which one becomes acquainted with the possible marriage partners in a region but also on the changing boundaries of what constitutes a region. A great many studies, on all parts of the globe, have demonstrated that most people tend to marry someone living close by. ${ }^{22}$ On foot in accessible terrain - that is, no mud, rivers, mountains, and gorges - one can perhaps walk 20 kilometres to another village and walk the same distance back on the same day. This distance comes close to the limit of trust that separated the known universe from the "unsafe" world beyond. If marriage "horizons" expanded, young suitors would be able to meet more potential marriage partners. The increase in the means and speed of transportation brought about by new and improved roads and canals, and by new means of transport such as the train, the bicycle, the tram, and the motorcar brought a wider range of potential spouses within reach. These new means of transport increased the distance one could travel during the same day, and thus expanded the geographical marriage horizon. ${ }^{23}$

In the course of the past two centuries, the average unmarried citizen

22. See, for example, Alice Bee Kasakoff and John W. Adams, "Spatial Location and Social Organisation: An Analysis of Tikopian Patterns”, Man, New Series, I2 (1977), pp. 48-64; Wesley Andrew Fisher, The Soviet Marriage Market: Mate-Selection in Russia and the USSR (New York, 1980), pp. 200-203; Barrie S. Morgan, "A Contribution to the Debate on Homogamy, Propinquity, and Segregation”, Journal of Marriage and the Family, 43 (198 I), pp. 909-92 I; Thomas W. Pullum and Andres Peri, "A Multivariate Analysis of Homogamy in Montevideo, Uruguay", Population Studies, 53 (1999), pp. 361-377; Stevens, "Propinquity and Educational Homogamy".

23. J. Millard, "A New Approach to the Study of Marriage Horizons", Local Population Studies, 28 (1982), pp. I0-3 I. Rosental sets the limit at 25 km; see Paul-André Rosental, "La migration des femmes (et des hommes) en France au XIX ${ }^{\mathrm{e}}$ siècle”, Annales de Démographie Historique, I (2004), pp. I07-136, esp. p. I09. Frans van Poppel and Peter Ekamper suggest a lower limit of 20 $\mathrm{km}$ in "De Goudse horizon verruimd. Veranderingen in de herkomst van Goudse bruiden en bruidegoms", in J. Kok and M.H.D. van Leeuwen (eds), Genegenheid en gelegenheid. Tree eeuwen partnerkeuze en buwelijk (Amsterdam, 2005). Kok and Mandemakers found that the degree to which a town or village was isolated had an effect on the degree of social homogamy; see Jan Kok and Kees Mandemakers, "Vrije keuze uit een beperkt aanbod. De huwelijksmarkt in Utrecht en Zeeland, I840-1940", in Kok and van Leeuwen, Genegenheid en gelegenheid. For a discussion of the effect of changes in transport on migration, see, for example, Collin Pooley and Jean Turnbull, Migration and Mobility in Britain since the $18^{\text {th }}$ Century (London, 1988), pp. $64-7 \mathrm{I}$ and $303-306$. 
will have met more marriage partners from his own social class and from other classes than previously. He or she will also have engaged more frequently in the gentle art of writing love letters. In the past two centuries the number of letters and postcards written per head of the population increased greatly. ${ }^{24}$ In a more recent phenomenon, millions of people even in geographically remote villages - are contacting one another on the Internet. Dating sites, where men and women specify their wishes and present what they have to offer in a favourable light, abound, but these are by no means the only way contacts are established using the Internet. Friends and potential marriage partners, however remote, are just a mouse click away, and their number seems almost unlimited. In the past, another important factor in bringing together young adults from different regions was the army. Conscription broadened the marriage horizon of the young men of a region by bringing them into contact with young women from elsewhere, and from other classes, notably when farmers' sons were barracked near the city. This geographical expansion of the marriage market could well have increased contacts between social classes, and so led to more exogamy.

While this might well have been the general rule, the broadening of the marriage horizon could also have had the opposite effect. Members of small social groups - or groups fair in size but dispersed over the country - could have been able to travel far enough to meet potential marriage partners from their own class, whereas previously they would have been prepared to settle for someone from another class. This scenario implies a strong desire to marry within one's own class, a desire frustrated by the lack of suitable candidates. While one can imagine various kinds of groups for which this was perhaps true - notably religious and ethnic minorities ${ }^{25}$ - it is more difficult to imagine it being the case for social classes, except for the elite, and wealthier farmers, where the desire to preserve the family's property or social status was an overriding issue. ${ }^{26}$

\section{Social pressure}

Parents, peers and other individuals or community institutions all play a part in the marriage process. In every country, past and present, the permission of parents has been required if children wanted to marry before

24. D. Vincent, The Rise of Mass Literacy: Reading and Writing in Modern Europe (Cambridge, 2002).

25. This can be seen as evidence of the fact that social-class relations were complicated and sometimes overridden by other allegiances. See Lex Heerma van Voss and Marcel van der Linden (eds), Class and Other Identities: Gender, Religion and Ethnicity in the Writing of European Labour History (New York [etc.], 2002).

26. One wonders to what extent it was also true for social groups with a modest amount of property, such as shopkeepers. 
they came of age, and this age has varied between countries and over time. Indeed, there have been societies, such as Imperial China, where children were legally subject to parental power until their parents had died. ${ }^{27}$ Apart from this formal power granted to them by law, parents usually have power by force of custom, or because they control the resources of the family. The parents might refuse to meet, host or house a potential spouse; they might shame him (or her) or otherwise attempt to deter the couple from marrying - by not contributing to the costs incurred by the newlyweds in setting up a household of their own (as was common practice for newly-weds in Europe), or by the threat of disinheritance for instance.

Parents from propertied classes could exert more pressure than those from the labouring classes. The customary way to become a farmer, for example, was to be born into a farming family, learn by helping one's father, and later on to inherit the farm; alternatively, one could marry the daughter of a farmer who had no son as heir. ${ }^{28}$ Similarly, a merchant's son would work at his father's office to learn the trade, and gradually take over more of his father's work until his father ultimately withdrew from the business. Assuming that parents normally prefer their offspring to marry someone from their own class, parental authority should lead to social endogamy, and the weakening of the legal and material bonds between parents and children over the course of the past two centuries should have led to greater exogamy. ${ }^{29}$

If parents wanted to influence their children's choice of partner, they could do so most effectively if they were both still alive. If either or both of the parents died before the child reached marriageable age, their influence would be lessened or rendered nonexistent. By the same token, however, with one or both parents deceased, pressure on the child to marry might have increased (one less mouth to feed), even if that meant marrying into a less desirable class. In fact, several studies have suggested that endogamy

27. Arthur P. Wolf and Chieh-shan Huang, Marriage and Adoption in China, I845-1945 (Stanford, CA, 1980); see also R.S. Watson and P. Buckley Ebrey (eds), Marriage and Inequality in Chinese Society (Berkeley, CA, I99I). In addition to parents, other kin might also have helped or hindered. See, for example, the role of grandparents and other kin in intergenerational mobility in nineteenth-century China, as described in Cameron Campbell and James Lee, "Social Mobility from a Kinship Perspective: Rural Liaoning, I789-1909", International Review of Social History, 48 (2003), pp. I-26.

28. Well-to-do farmers could supply the non-inheriting child with a farm or another livelihood during their life. See Dirk Damsma and Jan Kok, “ 'Ingedroogde harten?’ Partnerkeuze en sociale reproductie van de Noord-Hollandse boerenstand in de negentiende en vroeg-twintigste eeuw, 1940", in Kok and van Leeuwen, Genegenheid en gelegenheid.

29. If, on the other hand, parents prefer a degree of upward mobility for at least one of their children, for example their firstborn son, one would expect them to try to retain a greater grip on the eldest son than on his siblings. A decrease in parental authority over time would mean that the difference in endogamy practices between the firstborn son and the others would have slowly declined in the course of time. 
rates for children with two surviving parents were higher than those for orphans or semi-orphans. ${ }^{30}$ Perhaps the effect of missing one's parents varied according to gender. Granted that widowers remarried more often than widows, orphans whose mothers had died were more likely to have a step-parent than orphans whose father had died. If this created tensions (notably, as is sometimes claimed, between daughters and stepmothers), these would have been a reason to marry in order to leave the parental home as soon as possible, even if the marriage partner was not entirely socially desirable.

In some societies, parents exercised different powers over daughters than they did over sons. In Sweden, for example, in the nineteenth century, an unmarried woman never came of age; whatever her age, by law she had to ask a male relative (usually her father) for permission to marry. It was far from being a global rule, however, that daughters were subject to greater parental authority than sons. If the transmission of family status or property was an overriding issue, and if this took place down the male line - for example, where farms were handed over to the eldest son - then one can imagine that parents would have wanted a considerable influence over whom this son married, and have been content with less influence over whom their other children married. The effect of parental power on social endogamy may thus have differed according to gender and inheritance system.

Even if a young couple were lucky enough not to experience the constraints of parental power, they were still subject to the scrutiny of their peers. These peers might approve of a potential union with one of their own; but when marriages were considered unacceptable, due to large age differences or differences in region of origin, religion, or social class, they might disapprove and shame the boy or girl in question, and perhaps even beat them up, as happened in some regions. ${ }^{3 \mathrm{I}}$

Work evenings - sometimes referred to by the French term veillées were common throughout Europe. ${ }^{32}$ In the long winter evenings, the

30. F. van Poppel, J. de Jong, and A.C. Liefbroer, "The Effects of Paternal Mortality on Sons' Social Mobility: A Nineteenth Century Example”, Historical Methods, 3 I (I998), pp. I0I-I I 2; M.H.D. van Leeuwen and I. Maas, "Partner Choice and Endogamy in the Nineteenth Century: Was There a Sexual Revolution in Europe?”, Journal of Social History, 36 (2002), pp. I०I-I 23. 3I. On charivari see J.L. Flandrin, Les amours paysannes XVI-XIX siècles (Paris, 1975); Jacques Le Goff and Jean-Claude Schmitt (eds), Le charivari (Paris, I98I), and M. Segalen, Love and Power in the Peasant Family: Rural France in the Nineteenth Century (Oxford, 1983). One intriguing question, however, is whether charivari were usually related to social exogamy. Most seem to be about girls becoming romantically attached to boys from another village or town, about inappropriate age differences between lovers, and about extramarital relations. Were charivari perhaps rural phenomena, and thus a feature of populations that were socially rather homogamous?

32. M. Mitterauer, A History of Youth (Oxford, 1990), pp. 178-184; Edward Shorter, The Making of the Modern Family (New York, 1975), pp. I24-I27; Louise Tilly and Joan Scott, Women, Work and Family (New York, I978), pp. 38, 58, and i 87. 
unmarried girls of the village would join their mothers and potential suitors in a communal barn to work, mostly to spin, sing, and talk, perhaps dance, and to eat and drink. What the ballroom was for the urban jeunesse dorée, the veillée was for rural populations, except that the former had leisure, while the latter also had to work. It is often said that marriages were made in the veillée.

In large parts of Europe a tradition of "bundling" or night-courting existed, whereby groups of young men went off to visit young unmarried women with the intention of getting to know them, and ultimately of sleeping with them as a prelude to marriage. ${ }^{33}$ This practice was restricted to rural areas. There was pressure to marry the child of a farmer from the same village rather than someone from another village, or a travelling woodcutter from a completely different region. Farmers' sons were allowed to join a rural fraternity of older boys who assembled in the village, chiefly to organize courtship. On Saturday night, they assembled and went off together to call on the girls.

The fact that schooling has become both more universal and longer implies that the duration of peer pressure in school will have increased. Its extent, however, might well have decreased since schooling now encompasses all social groups to a greater degree than before, and most schools no longer instruct pupils on the wholesome virtues of rigid class boundaries. The duration of peer pressure in general has increased even more than the expansion in the educational system would suggest though, due to the growth in the nineteenth and twentieth centuries of an institutionalized youth culture, with sports clubs and the like. ${ }^{34}$

Another form of communal pressure was formed by the sermons heard at church. The priest, or other religious minister, might take a more liberal view of endogamy, or warn against the dangers of marrying above one's station. In extreme cases he might even name the culprit. His opinions reflected not just his personal convictions; they also reflected the teachings of his Church. And some religions might have been more restrictive than others when it came to marriage. It has been argued, for instance, that Catholicism has tended to be more conservative than Protestantism, particularly with regard to marriage, although both religions have presumably become less conservative over time. ${ }^{35}$

33. See the literature cited above, as well as K.R.V. Wikman, "Die Einleitung der Ehe. Eine vergleichende Ethno-soziologische Untersuchung über die Vorstufe der Ehe in den Sitten des Schwedischen Volkstums", Acta Academiae Aboensis Humaniora, XI (1937), pp. I-384; Van Leeuwen and Maas, "Was There a Sexual Revolution in Europe?"; Yochi Fischer Yonin, "The Original Bundlers: Boaz and Ruth, and Seventeenth-Century English Courtship Practices", Journal of Social History, 35 (2001/02), pp. 683-705.

34. Mitterauer A History of Youth, pp. 226-240.

35. J. Smits, W. Ultee, and J. Lammers, "Educational Homogamy in 65 Countries", American Sociological Review, 63 (1998), pp. 264-285. 
One might expect the size and homogeneity of a community to have influenced the degree to which it could exert pressure on non-conformists. In a small community which is homogenous with regard to norms on partner choice, the pressure to conform would have been greater than in a larger community, where one could escape social control or where several sets of norms co-existed.

Some scholars have argued that the power of parents, peers and the community has declined over the past few centuries. Segalen writes:

In traditional society, problems that would today be considered personal, whether to do with the intimacies of the heart or of the body, were the responsibility of the community. The formation of the couple, as well as concerning the young people themselves, involved the two families and the entire social group. [...]. Family considerations weigh heavily on the individuals, who tend to disappear in the face of the wider aims of economic and social improvement of the family line. In these terms the couple is merely a link in the chain leading to the growth of patrimony or resisting the fragmentation of landholdings through inheritance. The individuality of the couple, or rather, its tendency towards individuality, is crushed by the family institution, and also by the social pressure exercised by the village community as a whole. ${ }^{6}$

\section{Shorter claimed that}

There was a preference for custom over spontaneity and creativity. These little collectivities, be it the guild, the family lineage, or the village as a whole, correctly recognized that too much innovation would ring their death bell; and so they insisted [on] [...] the old ways of proposing marriage [...]. Once the heart began to speak, it would give instructions often entirely incompatible with the rational principles of family interest and material survival on which the small community was ordered. Marry the woman you love, the heart might say, even though your parents disapprove. 37

Shorter's sexual-revolution thesis belongs to a school of thought denoted as modernization theory. This school has long dominated sociological research into social mobility, including marital mobility and endogamy. In the field of endogamy Goode was probably the most eloquent spokesman of modernization theory. He wrote:

With industrialization, the traditional family systems are breaking down [...]. Elders no longer control the major new economic or political opportunities, so that family authority slips from the hands of such family leaders. The young groom can obtain his bride on his own, and need not obey anyone outside their family unit, since only the performance on the job is relevant for their advancement. They need not rely on family elders for job instruction, since schools, the factory, or the plantation or mine will teach them the new skills [...]. Nor do they even need to continue working on the land, still in the possession of

36. Segalen, Love and Power in the Peasant Family, pp. 38, 4I.

37. Shorter, The Making of the Modern Family, pp. 19-20. 
the elders, since the jobs and the political opportunity are in the city. Thus industrialization is likely to undermine gradually the traditional systems of family control and exchange..$^{8}$

\section{Personal autonomy}

From this outline, it might seem as if in their choice of partner young men and women were but clay in the hands of others. Of course this was not true. While social pressure could make it more difficult to marry outside one's social class, it was rarely impossible. Rather than imprisoning, starving, or killing non-conformists, they were forced to pay a price in the form of gossip, vile looks, nasty remarks, lost friendships, the denial of assistance, and being disinherited; those determined enough might decide that this was a price worth paying. Whether they paid was not entirely a decision of the heart; it also depended on their personal resources to withstand such communal pressure.

One such resource was the possibility of finding work at an early age on wages allowing one to escape the parental household and set up a place of one's own - or at least to remain with one's parents but with greater independence. It has, for example, been noted that the availability of factory work for young men and women with wages that peaked early in the life course gave them considerable leeway to do what they wanted. 39 These personal resources might have differed according to social class, region, and period. The existence of factory work in some regions and not in others, and the general rise in the availability of such work over time, will have favoured those born later and those born in industrial areas.

One factor so far missing from the discussion is the possible influence of social security schemes, with benefits being granted either on a meanstested basis or an insurance basis by the state or insurers. While some parts of Europe were characterized by poor relief provided by private and public agencies as well as insurance, especially on a mutual basis, from as early as the late Middle Ages, marked variations existed between regions, and great changes have taken place over time. Even today, when the marketing of social security is much stronger than it has been for decades, almost everyone in Europe turns to the state for financial support when they become seriously ill or reach old age, and, when truly in need, most of them will receive assistance.

While help by family, friends and neighbours is still very important in certain respects - as regards the time, love and care given to the ill and the elderly for example - the rise of state schemes has left people less dependent on their family (and on the Church for that matter: in

38. W. Goode, The Family (Englewood Cliffs, NJ, I964), pp. 108-109.

39. Shorter, "Female Emancipation"; Treiman, "Industrialization and Social Stratification"; Tilly and Scott, Women, Work and Family. 
continental Europe poor relief tended to be regulated to an important degree by the Church until well into the twentieth century). One might speculate then that there was an inverse correspondence between the degree to which such schemes existed ${ }^{4}$ and the need to comply with parental and communal pressure in such important matters as the choice of spouse. Furthermore, parents could afford to let children marry whomever they wanted to if they no longer regarded their children as necessary for their own future well-being. ${ }^{4}$ This might have been a factor contributing to differences between countries and to a gradual loosening over time of the grip of the collectivity in matters of marriage. ${ }^{42}$

\section{Personal preferences}

One can certainly be forgiven a degree of scepticism regarding our list of factors determining the choice of spouse. Surely, one might argue, personal preferences play a major role, and perhaps a larger role than any of the other factors usually mentioned. 43 And surely one would be right in

40. An overview can be found in J. Alber, Von Armenhaus zum Woblfartsstaat (Frankfurt, 1982).

4I. Smits, Ultee, and Lammers, "Educational Homogamy".

42. We have suggested that, since they needed to inherit the farm, farmers' sons were at the mercy of their fathers. This is only one side of the coin, however. Older farmers also needed heirs to take over their farms and provide for them in old age. "Retirement contracts" could be drawn up for this purpose, in which the owner of a farm yielded the usufruct of his farm to another person in return for food and shelter. This person was usually one of his sons, who promised to house his father - and mother - in either the farmhouse or in an annexe, and provide food, such as milk, beer, grains, meat, but also fuel and other necessities. The relative freedom on the part of the farmer to choose his heir encouraged high rates of endogamy. A farmer's son had an interest in pleasing his father by marrying a potentially good farmer's wife, i.e. a farmer's daughter. Marrying outside the farming class could harm his chances of taking over the farm. These contracts fell into disuse from the end of the nineteenth century onwards. One reason given for this is the rise of banks, which were willing to offer credit to buy a farm, and, indeed, of savings banks, where older farmers could deposit the proceeds from the sale of their farm (with the farmers then moving to live in the town). One could thus argue that in the heyday of the retirement contract, farmers with property had the sort of pension protection that other social groups lacked until the rise of the welfare state. Farmers with property lost that protection when retirement contracts fell out of use.

43. Compare the debate conducted in this journal by Wall, King, and Gillis: J.R. Gillis, "A Triumph of Hope over Experience': Chance and Choice in the History of Marriage", International Review of Social History, 44 (1999), pp. 47-54; S. King, "Chance Encounters? Paths to Household Formation in Early Modern England", International Review of Social History, 44 (1999), pp. 23-46; idem, "Chance, Choice and Calculation in the Process of 'Getting Married': A Reply to John R. Gillis and Richard Wall”, International Review of Social History, 44 (1999), pp. 69-76; R. Wall, "Beyond the Household: Marriage, Household Formation and the Role of Kin and Neighbours", International Review of Social History, 44 (1999), pp. 55-67. Wall stresses structural factors, notably of a social and economic nature, whereas King and Gillis emphasize chance and cultural factors. Our introduction discusses social, economic, as well as 
attributing importance to matters of the heart and other intimate desires. However, many such intimate forces of attraction are not just difficult to measure, they might also vary widely between individuals from the same social class. Historians and sociologists have seldom, if ever, studied beauty, kindness, humour, or good-naturedness as determinants of marriage patterns. Nor will we be doing so here either. This would be a grave omission only if such characteristics differed from one social class to another.

Almost any study of endogamy will show that people were more likely to marry others from the same social class, and that this cannot simply be explained by class sizes and random chance. ${ }^{44} \mathrm{~A}$ large number of other factors played a role. What concerns us here is the question of whether, in the absence of these other factors, young men and women would still prefer socially endogamous marriages. To answer this question, one has to consider what distinguishes an enduring intimate endogamous relationship from an exogenous one. One significant point is that individuals from the same social class are more familiar with the work that characterizes their class. Furthermore, these individuals are more likely to share a similar understanding of one another and the world, which might make a marriage easier (others, in contrast, prefer a partner with different tastes in order to make their marriage more "exciting"). Not only does a socially homogenous marriage increase the likelihood of the couple having the same tastes, it also makes it easier to undertake things together, to run a household jointly, to raise children (and to have the same attitude towards their partner). And, finally, it might be easier to trust someone from one's own social circle - to trust his or her tastes, character, and future earning capacity - than someone alien to it.

While it is not easy to formulate and test hypotheses on such preferences in the past, two such hypotheses do present themselves. Following Bourdieu, Kalmijn has argued that, ceteris paribus, most people prefer a partner who shares one's values and tastes, one's cultural background though many would not mind having a wealthier partner, i.e. someone from an economically higher class. ${ }^{45}$ The other notion we can research is

cultural factors. It notes that even "chance" meetings between certain individuals are influenced by structural factors such as group size and class differences in the likelihood of meeting, and that cultural factors could include the wish for a partner with the same values and tastes, which in turn is associated with social background.

44. See for example Hout, “The Association Between Husbands' And Wives' Occupations in Two-Earner Families"; Jerry A. Jacobs and Frank F. Furstenberg, "Changing Places: Conjugal Careers and Women's Marital Mobility”, Social Forces, 64 (1986), pp. 714-732; Kalmijn, "Status Endogamy in the United States".

45. M. Kalmijn, "Assortative Mating by Cultural and Economic Occupational Status", American Journal of Sociology, I00 (1994), pp. 422-452; Pierre Bourdieu, Distinction: A Social Critique of the Judgement of Taste (London, 1984). 
that individuals from propertied classes are inclined to marry one another. Having land and cattle made men and women from farming backgrounds attractive marriage candidates. Marriage among farmers was especially important since, to run a farm, a wife was needed to do the cooking, milking, and haymaking, while the husband did the other farm work. ${ }^{46}$ Endogamy among farmers was also important because it sometimes provided them with a means to enlarge the farm, or to keep it within the family. 47

The same can be said for the urban propertied classes..$^{8}$ From letters, diaries, and the like we know that in the nineteenth century the Dutch elite, for example, thought of marriage in the most exalted and romantic terms, but considerations of status and property were never far away either. ${ }^{49}$ The issue of the commensurability of love and property is an interesting one. The Dutch elite thought that to marry for the sake of money was vulgar, while marrying for love without money was foolish. Ideally one would have both, and parents took great care to create a circle of potential marriage candidates that would match their status; one of these candidates, it was hoped, would be "lovable".

According to some theories, the importance of personal preferences in the choice of marriage partner changed over time. Shorter claimed that after the end of the eighteenth century romantic love gained ground in the Western world: "the most important change in nineteenth- and twentiethcentury courtship has been the surge of sentiment [...]. People started to place affection and personal compatibility at the top of the list of criteria in choosing marriage partners. These new standards became articulated as romantic love." 50 If so, one would expect class homogamy in relation to

46. Mitterauer, A History of Youth; Segalen, Love and Power in the Peasant Family.

47. See Orvar Löfgren, "Family and Household among Scandinavian Peasants: An Exploratory Essay”, Ethnologica Scandinavia (1974), pp. 17-52, esp. p. 33; L.F. Saugstad and Ö. Ödegard, "Marriage Pattern and Kinship in Pre-industrial and Present-Day Norway", in S. Åkerman et al. (eds), Chance and Change: Social and Economic Studies in Historical Demography in the Baltic Area (Odense, 1978), pp. 84-94. Tilly and Scott, Women, Work and Family, p. 33.

48. "Curieusement le modèle bourgeois se rapproche du modèle paysan, dans la mesure où l'institution matrimoniale coïncide avec un 'établissement'. Au mariage, les parents transmettent une partie de leurs biens à leurs enfants; ils doivent donc en contrôler soigneusement la formation"; Martine Segalen, De l'amour et du mariage autrefois (Paris, I98 I), pp. 68, 85. See too George Alter, Family and the Female Life Course: The Women of Verviers, Belgium, I849-1880 (Madison, WI, I988), pp. I48-150, on the town of Verviers.

49. Thimo de Nijs, "Partnerkeuze in de hoge Rotterdamse burgerij I 8 I 5 - I 890 ", in Kok and Van Leeuwen, Genegenheid en gelegenheid.

50. Shorter, The Making of the Modern Family, p. I48. Stone too argues that this trend commenced in the late eighteenth century. See Lawrence Stone, The Family, Sex and Marriage in England I 500-I 800 (New York, 1977). Macfarlane, however, dates its beginnings much earlier: Alan Macfarlane, Marriage and Love in England: Modes of Reproduction, I300-1840 (Oxford, I986). 


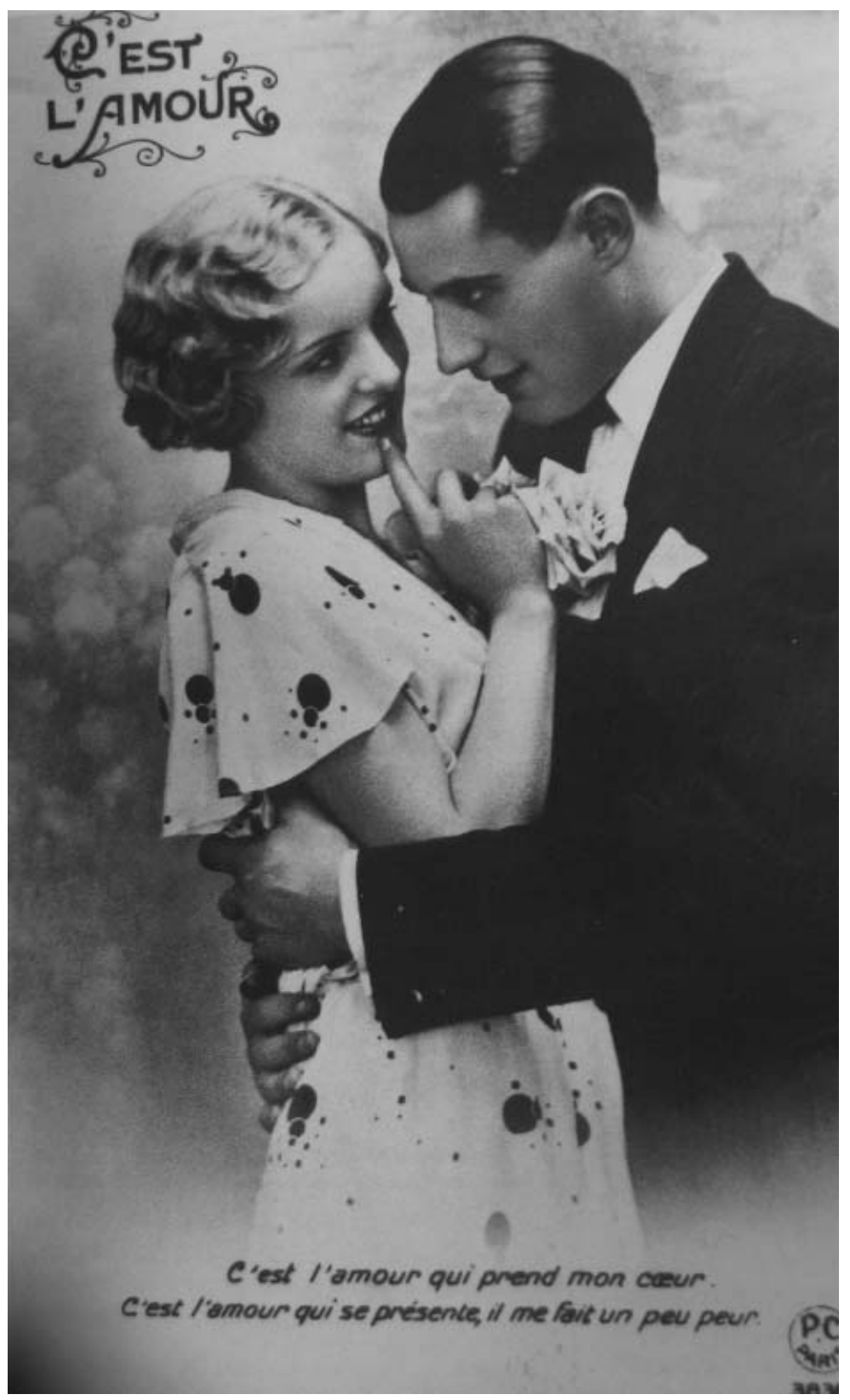

Figure r. "It's Love". Part of a series of five illustrated cards called "The Dream", written by Mathilde Janssens and sent to her fiancé, Félix Van Sweevelt, Antwerp, I9I3. Source: E. Van Driessche (ed.), Des accordailles aux épousailles. Galerie CGER, Bruxelles, I 9 février-I mai i 988 (Brussels, I988), p. 322. 
economic characteristics to have declined, but not perhaps in relation to cultural characteristics. ${ }^{\text {I }}$

\section{CONCLUSION}

Much of the literature on social endogamy is about patterns and their determinants; relatively little is about its consequences, and even less focuses on long-term changes. This is perhaps not surprising. Much of the theory originates with sociology, and the data that sociologists often use survey data - do not cover very long time spans. But long-term data do exist in the historical domain. Marriage records, census data, and other material are available in many countries across the globe for long stretches of time, and these can be used to test and refine theories on social endogamy.

In theory, there were evidently several groups of factors determining endogamy. Their relative strength over time can be discerned by relating endogamy patterns in countries and periods to the strength of the indicators of these determinants, which also varied by country and over time. It is worthwhile distilling the hypotheses on changes in social endogamy over time which have emerged from our review of the literature - if only because the literature deals more with structures and their determinants than with processes over time and their causes. Table I presents these hypotheses in a stylized way. Though this presentation shows a certain lack of regard for complicating factors, it serves a useful purpose and, we hope, will help others to identify simple ideas that can be tested against the historical data. ${ }^{52}$

Class formation is a central theme for social history. While the centrality of the theme and the availability of the sources are old, the articles in this volume are truly children of their time, firstlings of the twenty-first century. This is because only now has it become possible to classify historical individuals across regions and cultures into social classes in a similar way, using occupations as an indicator of social class.

Each of these articles addresses some of the issues raised here. Bras and Kok, using a large Dutch database covering the nineteenth century, test various hypotheses, including notions on the possible effect of being an orphan, being geographically endogamous, the career history of men and women, and the social relations and property structures of the various agrarian regions they study. They devote much attention to rural labourers, a social group sometimes overlooked in studies of class

ऽ. In order, however, to participate in certain cultural activities - such as attending classical concerts or expensive dance parties, or dining in chic restaurants - one does need economic resources. In other words, there is some association between cultural participation and economic position.

52. The body of this review article, though necessarily global, does differentiate according to possession of property, inheritance system, gender, group size, and type of religion. 
Table I. Hypotheses on changes in social endogamy over time.

\begin{tabular}{|c|c|c|c|c|}
\hline $\begin{array}{l}\text { Macro } \\
\text { characteristics }\end{array}$ & & $\begin{array}{l}\text { Effect on } \\
\text { social } \\
\text { endogamy }\end{array}$ & $\begin{array}{l}\text { Global changes } \\
\text { in macro } \\
\text { characteristics } \\
\text { over time }\end{array}$ & $\begin{array}{l}\text { Resulting } \\
\text { changes in } \\
\text { social } \\
\text { endogamy } \\
\text { over time }\end{array}$ \\
\hline \multirow{5}{*}{$\begin{array}{l}\text { Likelihood } \\
\text { of meeting } \\
\text { someone from } \\
\text { another class }\end{array}$} & $\begin{array}{l}\text { Universal } \\
\text { education }\end{array}$ & - & + & - \\
\hline & $\begin{array}{l}\text { Associational } \\
\text { life }\end{array}$ & + & + & + \\
\hline & $\begin{array}{l}\text { Ethnic/religious } \\
\text { diversity }\end{array}$ & - & $?$ & ? \\
\hline & $\begin{array}{l}\text { Modern labour } \\
\text { market }\end{array}$ & - & + & - \\
\hline & $\begin{array}{l}\text { Spatial social } \\
\text { segregation }\end{array}$ & + & ? & ? \\
\hline \multirow[t]{3}{*}{$\begin{array}{l}\text { Marriage } \\
\text { horizons }\end{array}$} & $\begin{array}{l}\text { Means of } \\
\text { transport }\end{array}$ & - & + & - \\
\hline & $\begin{array}{l}\text { Means of } \\
\text { communication }\end{array}$ & - & + & - \\
\hline & Conscription & - & + & - \\
\hline \multirow[t]{4}{*}{ Social pressure } & Parental control & + & - & - \\
\hline & $\begin{array}{l}\text { Communal } \\
\text { traditions }\end{array}$ & + & - & - \\
\hline & $\begin{array}{l}\text { Peer group } \\
\text { control }\end{array}$ & + & $?$ & $?$ \\
\hline & Adult mortality & - & - & + \\
\hline \multirow[t]{2}{*}{$\begin{array}{l}\text { Personal } \\
\text { autonomy }\end{array}$} & $\begin{array}{l}\text { Economic } \\
\text { independence at } \\
\text { early age }\end{array}$ & - & + & - \\
\hline & $\begin{array}{l}\text { Social security } \\
\text { schemes }\end{array}$ & - & + & - \\
\hline $\begin{array}{l}\text { Personal } \\
\text { preferences }\end{array}$ & $\begin{array}{l}\text { Notions of } \\
\text { romantic love }\end{array}$ & - & + & - \\
\hline
\end{tabular}

formation. So, too, do Dribe and Lundh, Arrizabalaga, and Bull. Dribe and Lundh note the existence of rural retirement contracts as well as bundling or night-courting in their Swedish parishes in the nineteenth century, as does Bull for the Norwegian valley he studies in the period I750-1900.

Interestingly, Bull suggests that "the introduction of the ideal of romantic love led parents to control the mating process even more firmly. If children risked losing their way in the process of night-courting, falling 
in love with the wrong person, parents would take action to prevent this from happening." Dribe and Lundh look at the effect of property on social homogamy, as does Arrizabalaga. Arrizabalaga also looks at the various options available to men and women in the French Basque country in the nineteenth century to improve their fate - and at the differences between these men and women: marrying someone from the same class (heirs of propertied families and the landless); migrating to America (men of all classes); migrating to the city and remaining single, or marrying a cotter locally (daughters of propertied farmers).

Lanzinger looks at a small conservative Austrian market town, in what is now part of Italy, in the period 1700-1900. Marriage in this society was regulated through settlement policies, which barred undesirables from moving to the community. By law, only citizens with property could marry. Every couple had to prove that they could financially support a family - otherwise they would not be allowed to marry. This law was introduced in I 820 and in some areas remained in effect until as late as I923.

The four Belgian authors - Van de Putte, Oris, Neven, and Matthijs test various assumptions on a large database covering both rural and urban areas in both the French- and the Dutch-speaking parts of Belgium in the nineteenth century. They analyse the effect of migration, occupational identity, and ethnicity (in the form of language barriers) on social homogamy. The effect of both short- and long-term migration on marriage patterns according to social class forms the core of the article by Pélissier, Rébaudo, Van Leeuwen, and Maas. They study a large nationwide sample covering France in the nineteenth and twentieth centuries. They address such questions as: Did migrants constitute a permanent proletariat? Does the direction (rural-urban or urban-rural) of migration matter? Do wars make a difference? What is the effect of social pressure, notably that exerted by parents? Did the expansion in marriage horizons matter?

Schumacher and Lorenzetti, in their contribution on the Swiss town of Winterthur, are particularly interested in the association between social structure, social endogamy, and class relations. They derive a socialstratification scale from marriage patterns and, on the basis of these patterns, investigate whether the great national strike of I9I 8 increased class consciousness.

Holt looks at both formal Catholic marriages and informal, consensual unions of enslaved and free Brazilians in a plantation society during the nineteenth century. How did Brazilians cope with the rather rigid class and racial hierarchies that characterized plantation life? Could a free or freed woman marry a wealthy planter, and if so could their child pass for white? What were the benefits of formal marriage, and at what cost did they come? Which layers of society entered consensual unions and why did they do so? Were there differences between men and women in the costs and benefits associated with these two types of marriage? 
There are many insights to be derived from comparative historical studies of class formation; insights, we believe, that are central to social and labour history. Many more, indeed, than can be dealt with in this volume, and also more than is at present possible. But this volume can perhaps help to give the topic the prominence it deserves. Furthermore, the conclusion to this volume presents the first truly comparative - in the sense of using the same social-class scheme - study of social endogamy in the past. Were there significant territorial differences, and if so what were they? Did they change over time, and if so how quickly and in what direction? Were temporal changes a mere reflection of changes in class structure, in particular the decline of the endogamous class of farmers, or were these temporal changes still evident even after the influence of changes in class structure had been filtered out? In short, was society becoming more open as well? And what do the marriage patterns observed tell us about the social distance between classes? 